\title{
Urban Land Use Conflict in Expansion Areas of Wolayta Sodo Town, Snnpr, Ethiopia
}

\author{
MILKIAS ISRAEL GALLASO, SHUKUI TAN (Professor), Qing Yang (Maria) \\ Huazhong University of Science and Technology Wuhan 430074, P. R. China
}

\begin{abstract}
The previous studies on urban land use conflicts indicated that extensive negative effects on economic, social, spatial and ecological development, especially in peri-urban areas. The study assessed the causes and effects of urban land use conflicts in peri-urban areas and its measures to prevent in Wolayta Sodo town. The survey design method was employed as a case study approach targeting in peri-urban areas households or landowners population. From the total nineteen administrative kebeles of the town, eight kebeles selected as clusters and from which five kebeles randomly selected. Questionnaires were to 357 households administered from each cluster selected by simple random sampling techniques. Focus group discussions were employed with town municipality and subcity, and local chief and police. Additionally, key informant interviewee addressed with regional, zonal, and Wolayta Sodo town municipality Urban Development and Housing department. Spatial data collected from field survey, and satellite imagery. Purposefully three types of urban land use conflict selected and analyzed. Data analysis tools were MS-excel, Likert scale and GIS software. The finding shows that the dumping soil on the road reserve, land encroachment, boundary dispute, and land grabbing were frequently occurred. Also, the finding indicated that land usufruct right conflicts and degradation of road access were prevailed in expansion areas of the town. The major causes for an urban land use conflicts in the area were lack of land ownership documents, double allocation of urban plots, inadequate compensation for landholders and their children's inheritance rights, poor land governance, and forcibly expropriating. The other causes are inadequate planning and non-implementation of planning regulations, and lack of public participation in urban development agenda. The effects were social, environmental, and economical to the society. Therefore, the study recommends immediate adequate planning, public awareness and implementation measures, creating an efficient and effective land management system, professional ethics and policing, and paradigm shift on issues related to land uses.
\end{abstract}

Keywords: land use conflicts, peri-urban, preventions, resolution

DOI: $10.7176 / J R D M / 52-01$

\section{INTRODUCTION}

\subsection{Background to the Study}

Urbanization recognized as one of the most powerful and irreversible forces in the world, especially in developing countries. The process of urban expansion shifts the agricultural land to an urbanized land use, which is bringing a large concentration of people into towns and cities (World Bank, 2005). Therefore, the process of urban expansion may involve both horizontals and vertical expansion of the physical structure of urban centers, especially in peripheral areas. Additionally, it can result in loss of agricultural land, natural beauties, rangelands, parks, and scenery (Minwuyelet, 2004).

Ethiopia urban areas have grown very fast similarly with other developing countries which have led everincreasing demand of land from peri-urban areas for housing and other non-agricultural activities (Adam, 2009). The critical problems are lack of appropriate land use policies, laws, and adequately enforced regulations; lack of update data of spatial and socio-economic data; poor titling results in tenure insecurity; and lack of community involvement and failure of institutional capacity that can occur in Ethiopia as well as to the study area on Wolayta Sodo town (SEC, 2015). Consequently, defining the boundaries of urban, peri-urban and rural areas is not straightforward in the country. Such kind of an urban expansion has been the sources of increasing numbers of land conflicts due to different parties have incompatibility of interests on a piece of land (Fikadu, 2015).

Land use conflicts result of competitive demands from present to future uses of the land, causing a negative impact on other land uses (Magsi, 2013). Urban land use conflicts consists an extensive negative effect on economic, social, spatial, and ecological development, especially in peri-urban areas. Moreover, the causes of urban land use conflicts are illegal land encroachment; inadequate compensation for landholders for their property and for their children's inheritance right, lack of public participation and a widespread reaction of inhabitants' results in tension and it may lead to conflicts as reported Ethiopian press. This study applied to the town, which has recorded rapid urban expansion rate during last ten or more that decades as result of rapid population growth and economic development. However, the urban expansion becoming irregular, fast, and it causes conflicts on land use in the town due to an incompatibility of interests, and which lead to urban land use conflicts in the area. 


\subsection{Objectives of the Study}

\subsubsection{General objectives of the Study}

The general objective of this research was to assess the causes and effects of urban land use conflicts in expansion area of Wolayta Sodo town and pointing its future policy implications for sustainable urban development.

\subsubsection{Specific objectives of the Study}

$>$ To assess the nature and causes of urban land use conflicts in expansion area of Wolayta Sodo town.

$>$ To assess the effects of urban land use conflicts on social, economic, and environmental around the expansion areas of Wolayta Sodo town.

$>$ To assess the local government measures to prevent and resolve land use conflicts in the study area.

$>$ To recommend possible measures that may reduce negative effects of urban land use conflict in expansion area of Wolayta Sodo town.

\subsection{Research Questions}

The following research questions addressed based on the background of the study and statement of the problem.

1. Why urban expansion leads to land use conflicts in Wolayta Sodo town?

2. What were the effects of urban land use conflicts on social, economic, and environmental around the expansion areas of Wolayta Sodo town?

3. What the local government undertakes the measures to prevent and resolve urban land use conflicts during land expropriation in expansion area of Wolayta Sodo towns?

4. What is the possible measure that may reduce negative effects of urban land use conflict in expansion area of Wolayta Sodo town?

\section{REVIEW of RELATED LITERATURES}

\subsection{The Concept of Tensions and Conflicts on Land}

Land is a basic natural resource for economic development but today it has reached a stage of scarcity in urban areas because of rapid urbanization. Most of land conflicts involve power relationship between those who have access and control means to land and those who are struggling to grasp the opportunities (Myenzi, 2011). Frequently, conflicts occur when individuals become involved in either promoting or opposing a project from being realized (Anna et. al., 2015). Additionally, Magsi, (2012)stated that the conflicts always vary in terms of their legal, political and institutional framework, economic constraints and pressures, social structure, stakeholder's interest, environmental situation, the history of behind the conflict and for their geographical location.

Magsi (2013) study show that urban land use conflicts besides the infrastructural projects and urbanization have also seemed a source of land use conflicts in developing countries. Thus, if proper attention does not pay it might be a big land use conflict. Peri-urban areas are often subject to intensive construction, through both formal and informal processes (Lombard, 2016). As land transitions from rural to urban status, different land tenure and administration systems may come into conflict, leading to disputes, contestation and, in some cases, violence (Ibid). Similarly, most of the Ethiopian city administrations (municipalities) are finding it increasingly difficult to cope with the demand for registering the process of land transactions as well as the rapidly changing patterns of land use associated with the accelerated urban growth (Ashenafi, 2015). Moreover, Wehrmann (2008) states that all land conflicts, no matter how peaceful or violent they might produce negative consequences for individual people as well as for the entire society. Many families across the world have seen their shelters and homes bulldozed out of existence. Lucy (2014) stated that in African daily experience the selling of their property by someone else who also claims to be the owner. Conflict must exhibit all of these components and must take place between identifiable actors; otherwise applying the concept of conflict will be a misleading object (Magsi, 2013).

\subsection{Conceptualizing Land Use Conflicts}

Swanström and Weismann (2005) stated that to identify appropriate focus on conflict analysis issues are different from grassroots to the national level but it is crucial. Conflicts are not static situations, some conflicts seem to be straightforward and easy to deal with, while the others not (Ibid).However, understanding the dynamics of conflict concepts through different possible developments and thinking with appropriate responses to the opportunity windows identified. Conflict must exhibit all of these components and must take place between identifiable actors; otherwise applying the concept of conflict will be a misleading object (Magsi, 2012).A number of factors taken into account in order to analyze the conflict, including the conditions which create favorable environments for its emergence, causes, which precipitate the conflict, the expression of conflict, the dynamics of conflict, and the consequences and legacies of conflict (Magsi, 2013). Conflict analysis occupies an important place in social science literature and it subjected to a systematic study of the causes, actors, conflict profile, and its dynamics (Ibid). In this regard, it is important to understand the conflict concept as described in figure 1, its various components, situations of actors evolved and their perceptions, to move towards integration of these perceptions for further analytical treatments. 


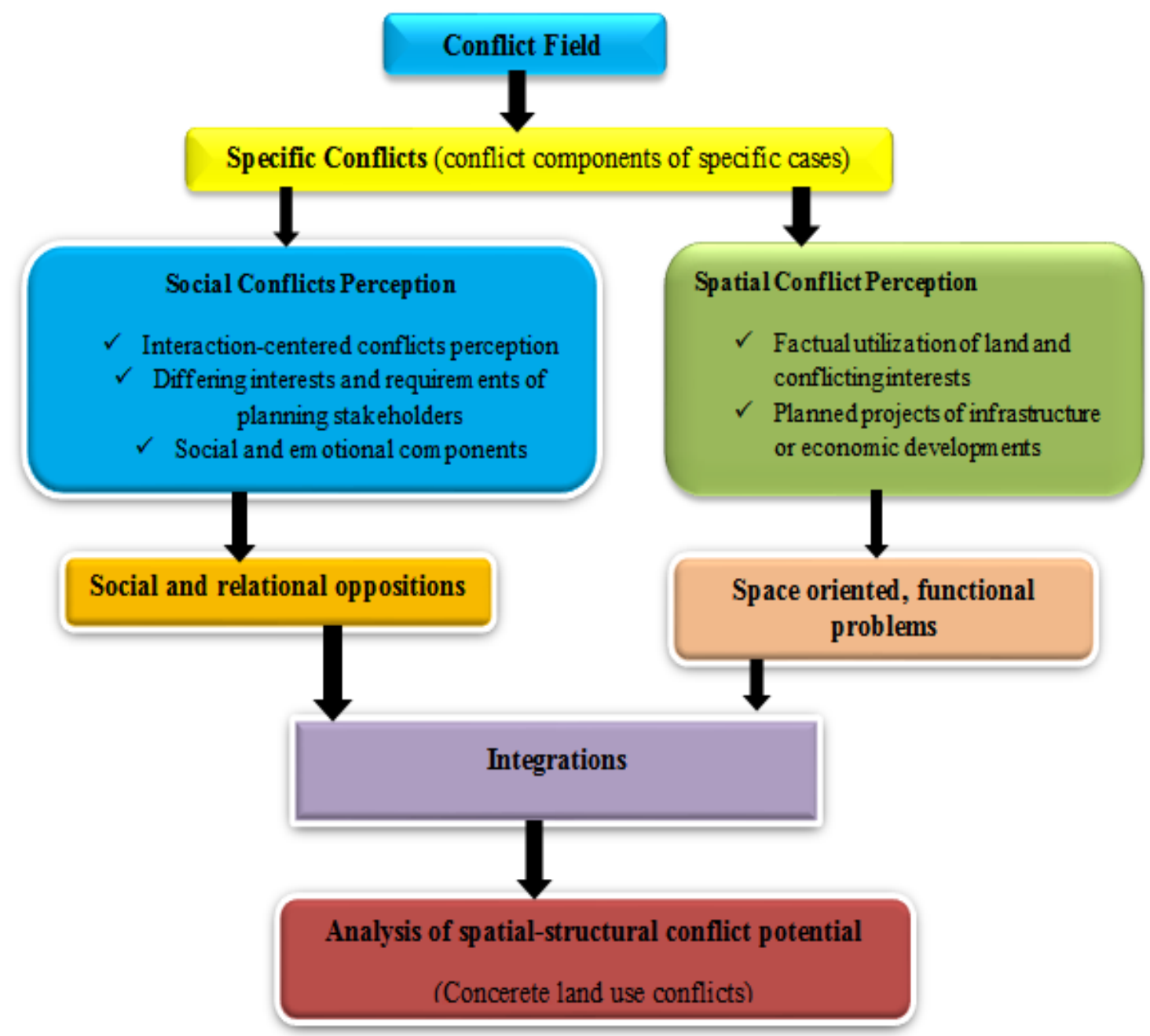

Figure1: General Conflicts Relationships with Land Use Conflicts (Source: Adopted after Magsi, 2012)

The concept of the conflict identification described in the above figure 1 indicates that there is always mutuality within spatial and social conflict perceptions, even in general cases. The nature of land use conflict requires that spatial elements integrated to the collaborative decision-making process. In order to develop a consensus between the stakeholders and to build a common platform to analyze conflict effectively was an essential in social and spatial cases.

\subsection{Land Use Conflict Identification Strategies}

Jones et al. (2005) described different types of land use conflicts according to the involvement of stakeholders and their temporal and spatial scale. In addition, their spatial and social concern may vary related to the involvement of local actors and to their ability to recruit new participants or supporters in the upcoming stages (Ibid). Broadly speaking, the conflicts can be compound and complex, but they can be categorized as; the conflicts related to personal differences or preferences with small individual actions (interpersonal conflicts) and the conflicts related to distribution of power among groups (structural conflicts), which are strongly linked to public decisions with a great social impact (Magsi, 2012).

The theory of structural conflict has its own usefulness because it provides a conceivable explanation for a large agglomeration of economic, social, and politic vectors that influences groups, which eventually in conflict to be clashed (Magsi, (2012). For example, table one show that the relations between structural conflicts related to land use conflicts.

In general, land use conflicts are being practiced in places where competition and expectation of land use exist, as well as where the decision on future land uses may face the risk to favor only selected stakeholders (Magsi, 2012). The conflicts also emerge when the legal rights of land owners have misused and the economic benefits of the land use will be too far from its present uses (Ibid). However, the chain of structural conflicts described in the below table is more related to the conflicts over land use, which is the result of misuse of stakeholder's power. Therefore, land use conflict can be define as it is the result of the competition towards actual to future use of the land, which will have a higher probability confrontation. 
Table 1: Structural conflicts may relate to land use conflicts

\begin{tabular}{|c|c|}
\hline $\begin{array}{l}\text { Aspects of structural } \\
\text { conflicts }\end{array}$ & Related Land Use Conflicts \\
\hline Social & $\begin{array}{l}>\text { Unrepresentative social structure: inequality and unjustness. } \\
\text { Different level of education or income: use of illegal channels and non- } \\
\text { negotiated ways. } \\
>\text { Insecurity of tenancy or ownership: exploitation of natural resources. }\end{array}$ \\
\hline Economically & $\begin{array}{l}\text { Government policies ignoring ownership norms and local people needs } \\
\text { Misuse use of economic and political power } \\
\text { Biases structure towards certain stakeholders: some institutions are inherently } \\
\text { political }\end{array}$ \\
\hline Culturally & $\begin{array}{l}\text { Different values and definitions held by indigenous and people and migrants } \\
\text { Negative views between one another groups } \\
\text { Some groups exploit racial, religious, cultural or language differences and } \\
\text { intolerance }\end{array}$ \\
\hline Legally & $\begin{array}{l}\text { Legal system misuse: over favour to certain stakeholders. } \\
\text { Inaccessibility: poverty and geographic distance may prevent people to get } \\
\text { access to legal systems. }\end{array}$ \\
\hline
\end{tabular}

Source: Adopted from Magsi 2012

\subsection{Urban Expansions and Land Use Conflicts}

Anna Locke (2016) explored the urban expansion rates over the coming decades are expected to be observed in developing country especially Sub-Saharan Africa, with predicted a 12-fold increase in the urban land cover surface between 2000 and 2050. The biggest absolute growth expected to occur in countries with large populations and relatively low urban population between the years 2010-2050 (UN-Habitat, 2007). However, UN-Habitat, (2014) states that the current rates of urbanization in Sub-Saharan Africa lower than sometimes suggested, the region is expected to urbanize at a higher rate than other parts of the world. Between 2010 and 2050, the number of Africa's urban dwellers expected to increase from 400 million to 1.26 billion (Ibid). Africa-wide, the proportion of people living in urban areas projected to reach $50 \%$ by around 2035 , and almost $58 \%$ by 2050 under a moderate growth rate projection (Ibid).

Ministry of Urban Development and Housing (2015) described that the recent Ethiopia urbanization level was $20 \%$ and urban population growth rate was $5.4 \%$ per year. These indicate that the level of urbanization was low which is $37 \%$ compared even if with eastern African countries standard. UN-Habitat estimates that the urban population of Ethiopia is expected to triple between 2010 and 2040, growing at an average rate of 3.5 percent per year. Additionally, Ethiopian urban growth rate was $4.1 \%$ per year and this was very high from $3 \%$ total population growth rate in the country and 3.5\% urban growth rate in Africa. The cities fast growing like Hawassa, Mekele, Adama and Bahir Dar in 2010 their population will grow more than 6-fold, 5-fold, and both 4-fold respectively. At the same time, built-up areas of these cities will be expected to expand at an even faster rate than their population growth (UN-Habitat, 2010).

Table 2: Ethiopian urban growth trends since 1952

\begin{tabular}{|l|c|c|c|c|l|l|l|}
\hline Year & 1952 & 1976 & 1986 & 1999 & 2006 & 2008 & 2017 \\
\hline Urban growth rate by \% & 6 & 11 & 14 & 16 & 17 & 20 & 30 \\
\hline
\end{tabular}

Source: CSA, 1976 - 1999 and MoUDC, 2014 abstract data

Table 2 described that the level of urban growth in Ethiopia increasing in rapid rate which has been only 6 percent in 1960, and which has increased to 11 percent in 1984 and 14 percent in 1994, which have 17.2 percent by 2013 (CSA, 2015). The level of urbanization was slow in 1952 to 1976 and record fast growth since 1999. UN settlement (2012) stated that $25 \%$ of urban population growth from expansion area in Ethiopia contributed to population growth in the country. Additionally, World Bank (2012) states that in Ethiopia 33\% migrants for job opportunity; $67 \%$ migrants migrated for other purposes in the cities or towns. For example, central statistical agency data indicate that in Addis Ababa 47.6\%, in Hawassa 60\%, in Mekelle 52.2\%, in Dessie $48.3 \%$ and in Jimma50.6\%, peoples were migrated to urban centers in 2014.

Furthermore, the high demand for land has led to its use conflicts either in rural or urban areas. Magsi (2013) studied that in developing countries local inhabitants not being counseled even not asked for their views on the decisions on the initiation of the development projects. However, before planning towards a development projects a redress system related to land acquisition, compensation and resettlement should be clearly established, which should ensure that affected population may regain their former living standards and prestige (Magsi, 2013). Moreover, Darly and Torre (2013) described that the land use conflicts are the forms of expressions of opposition to the decision that leave part of the local population unsatisfied. 
Magsi (2012) the land use conflicts are being practiced in places where competition and expectation of land use exist. In urban expansion area many forms of the clash of interests between different actors for use of the same piece of land. Definitely, land use conflict is a serious issue of the century, especially in developing country. Therefore, conflicts also emerge when the legal rights of landowners have misused and the economic benefits of the land use will be too far from its present uses.

\subsection{Sources of Land Use Conflicts}

UN (2005) stated that conflict in itself a constructive element of a dynamic society; however, it becomes very problematic when the parties to a conflict resort to violent means to advance their causes. Moreover, Magsi (2013) explained further that multiple and extremely complex land-related conflicts affect indigenous peoples, particularly when their identity and survival is inextricably related to their relationship with their ancestral territories. Conflict exists when two or more actors/parties are mobilized to obtain incompatible goals/interests where the other party perceived to stand in the way of these goals (Wehrmann, 2008). Anna et al. (2016) described that an aspiration of land-use planning is to coordinate current and future societal needs while minimizing conflicts. Recently, planning has focused mainly on conflict negotiation, focusing for example on communication and community engagement (Ibid). However, urban planning in country lacks professional policing, up-to-date data and lack of appropriate legal grounds. The different literature described that three main sources of land use conflicts in developing country such as tenure based or usufruct right conflicts, parcel boundary conflicts and environmental based conflicts.

\subsubsection{Lack of land tenure security}

Magsi (2012) described the property rights are critical for economic growth and sustainable development as well as for good governance and stability. UN-Habitat (2007) identified the tenure insecurity resulting in conflict as one of the several increasingly serious threats to urban security and safety alongside disasters and violence. Rapid urban development leads to swift and drastic changes in the physical, economic, social, political and administrative structures of the cities was emphasized (Yusuf et al. 2009). Rising urban land values, compounded by urban growth, have resulted in a severe security of tenure crisis (UN-Habitat, 2007). Insecure tenure rights leads to constant threat of (violent) eviction; limited or no access to basic services; and social exclusion and homelessness (Ibid). The other problem is reduced revenues for local government; gender violence; reduced housing investment and distortion in land prices; and weakened governance and long-term planning (Ibid).

Land and property rights regimes can differ significantly between rural and urban areas, often moving from customary tenure in more remote rural areas to more individualized forms of tenure in urban areas (Naab et al., 2013). Anna (2016) stated that urban expansion into the peri-urban areas of towns and cities can lead to suboptimal configurations of land use in the absence of pro-poor land use planning. On the other hand, Lombard (2012) stated that titling land might contribute to increased tenure security through many alternative forms of tenure, including those in many informal settlements, also provide high levels of security. However, land tenure legalization is not only a response to conflict over land rights but also a potential generator of land disputes (Lucy, 2014).

Furthermore, as Ethiopia constitutions the power to "enact laws for the utilization and conservation of land and other natural resources, historical sites and objects" is provided under the constitution to the Federal government(FDRE, 1995 article,51 (5)). Consequently, the Federal government enacted an urban land lease proclamation $721 / 2012$ and proclamation No.-455/2005 about compensation. The legal framework delegates regional states with the power to enact land use regulations and directives which consistent with it. Also, the council of ministers regulation No.-135/2007the compensations for the property during land expropriation have implemented. However, the different empirical study in urban expansion areas of Ethiopia land tenure insecurity is more visible in peri-urban areas. Also, the governmental institutions' report indicated that the implementation of rules and regulation has faced critical problems.

\subsubsection{Boundary disputes}

Lucy (2014) study described two types of parcel boundaries in Kenya; general and fixed boundaries. General boundaries are boundaries that are of descriptive nature and are usually determined by adjudication and demarcated by hedges. Their accuracies are low and relative to their source of the description, which is mostly historical and relative to fixed physical features (Ibid). Their re-establishment is the responsibility of land registrars who are supposed to listen to the history of the boundary position and determine their correct position, the registry assisted by the Surveyor as the need may arise (Ibid). Fixed boundaries, as the name suggests that mathematically fixed by geographical coordinates and mathematically re-established by a Government Surveyor. Most of these fixed boundaries found in urban areas and leasehold properties.

Robert (2010) studied that the U.S. surveyors' role in boundary disputes between neighbours over their common boundaries are ubiquitous. The source of the disputes quite often within the realm of the surveyor's expertise found. Boundary disputes between neighbours can be wretched affairs known to destroy neighbour relations, especially in developing countries. Sometimes the financial cost of litigation frequently exceeds the 
value of the land concerned and even when land in dispute is very small, litigation may ensue because of the critical location of land in dispute or its strategic importance to the owners concerned (Lucy, 2014). He found that boundary disputes have their origin in the replacement work of a surveyor and most of them are caused by either inadequate, erroneous legal descriptions, obscure or ambiguous conditions on the ground. The surveyor and the attorney have distinctly different roles in dispute litigation. In Ethiopia, the descriptive nature of boundary appeals mostly in rural areas and similarly with Kenya fixed boundary in urban areas. However, the land use conflicts appeal due to double allocation of single urban plots to more persons.

\subsubsection{Environmental based land conflicts}

Feyera (2005) enlightened about urban expansion does not accompany by environmental protection system. Wu J. and Irwin E. (2008) stated that the land use change is a pervasive socio-economic force driving change and degradation of ecosystems. The different literature stated urban development resulted in deforestation, urban development, agriculture, and other human activities have substantially altered the landscape. Such disturbance of land affects the important ecosystem system. Also, Feyera (2005) studied has shown that the urban waste relies on open canals, open drains in the roadside and holes in the ground as regular means of waste disposal, particularly in expansion areas. Lucy (2014) described that peri-urban area is not only a zone of direct impacts on land demands from urban growth and pollution of air but it is also a wider market-related zone of influence. Accordingly, Ethiopian urban centers have faced environmental based conflicts like dumping solid and liquid wastes on open spaces and it can cause sanitation problem for local habitants (SEC, 2015).

\subsection{The Approaches of Conflict Resolution and Prevention Strategy}

In principle, big conflicts are mostly arising in the situations of growing inequality among the population, misuse of political strategy, lack of democracy, as well as due to uncertain and weak institutions. Moreover, a dynamics of conflicts sometimes become complex and difficult to understand, when conflicts comprise a large number of issues. The difficulty reflects that such complexity must also be taken into account while addressing how to resolve or prevent (Swanström and Weissmann, 2005). Consequently, conflict prevented by the intervention of sustainable development, economic growth, security insurance and good governance (Lucy, 2014).

\subsubsection{Land use conflict resolution strategies}

Magsi (2013) discovered the conflicts settled or resolved through different approaches according to the degree to which they emphasize. Different conflict resolution approaches suggest diverse mechanisms. Despite defined legal frameworks in an economy, the decision-making process does not seem able to resolve the opposition and competition over public utility projects, because it may be either due to loopholes in the governance structure or institutional failures or contradictions at local and/or national level(Ibid). Furthermore, Crane et al. (2009) have explored that politics of land use conflicts resolution approach ensure that all cannot be negotiated, but there will always be winner and loser; similarly, Ostrom and Nagendra (2006)cited in Magsi (2013) have also suggested that not all type of governance seemed to resolve the conflicts completely.

Magsi (2012) stated that the land use conflicts in developing countries may be resolved by adopting the strategy prior to determining causes and consequences of the decision for use of land and the relationship between actors/stakeholders involved; and actualities of situations faced by local population, might have a higher probability of success. Whereas, Wehrmann, (2008) described that land conflicts between single parties, inheritance conflicts between siblings and disputes over the use of a given piece of land are comparably easy to solve. Therefore, the concept of conflict describes a type of relationship between actors and refers to a situation between them, their behaviors, their attitudes, and perceptions.

\subsubsection{Conflict preventive measures}

Magsi (2012) described that land use conflict prevention in developing economies is not an easy task. Therefore, there can be two main obstacles such as lack of democracy on one hand, and the relative ignorance of local populations on the other hand (Ibid). These failures can lead to extreme situations to the infrastructural projects without or partial involvement of stakeholders. Swanström and Weissmann, (2005); Ackermann, (2003), studied that the land use conflict prevention normally has two dimensions which consist of operational prevention, such as immediate measures applicable in the face of crisis, and structural prevention. Correspondingly, these two main dimensions can further be distinguished as; operational or direct conflict prevention that measures to address the immediate crisis or tension (Ibid). Structural prevention or root-cause prevention addresses the basic causes of the conflict on which the conflict can be structurally prevented by the promotion of rules of laws and the development in the region, thus a broad-based economic growth could also be achieved (Swanström and Weissmann, 2005). For example, promoting democratic governance so that opposing actors may state their views without any fear, resolving differences through cooperative dialogues or ensuring legislation should not discriminate against one sector of the society (Magsi, 2013). Also, Swanström and Weissmann, (2005) describe that economic development assistance or increased political participation is examples of structural prevention. Conflict management and conflict prevention have, in a similar way, argued to be different sides of the same coin. It has also argued that conflict management is required in order to enable the initiation of preventive measures aiming at resolving the 
dispute (Ibid).

Magsi (2012) study explore done of the best solutions to avoid such conflicts at an early stage is to keep local populations informed, in order to improve their knowledge about the development projects, as well as to increase the level of local democracy. This method will lead to discussions about main goals of development projects and can bring solutions to technical problems as well (Ibid). At the same time Magsi (2013) states the economic development and integration may be an effective conflict preventive tool and it helps to build stronger institutions. Perhaps, the development efforts can significantly contribute to conflict prevention, particularly if it implemented in a conflict-sensitive manner (Ibid). Because any decisions made beyond the conflict sensitivity will lead to deep understanding of the conflict dynamics, which will further potentially contribute in its factual prevention (Ibid).

\subsection{Effects of Urban Land Use Conflicts in Expansion Area}

Fikadu (2015) studied that urbanization has also some negative effects to its surrounding peri-urban areas in different aspects. Urban centers expand by occupying fertile farmland, and displacing farmers cause to reduce the amount of production and number of family farmers and move to the nearby urban centers (Ibid). Presently in Ethiopia, land taking by regional governmental for urban expansion and towns is expanding rapidly because urbanization leads to outward expansion of cities and results to change in land use and landscape whereby the federal and regional agencies and the municipality are expropriating of agriculture land for public purposes (Fikadu, 2015).Also, Wu, J. and Irwin, E. (2008) studied urban development has come up with many environmental problems, including air pollution, water pollution, and loss of agricultural lands(Ibid). Additionally, HAKIARDHI (2009) stated that the land conflicts have never passed without causing negative consequences to the land users, the community, and properties. Therefore a lot of resources are wasted which could have been used for development activities and leaving the majority people in extreme poverty.

\section{RESEARCH METHODOLOGY}

\subsection{Research design}

Cluster sampling involves grouping the population and selecting the group or the cluster rather than individual elements for inclusion in the sample (Kothari, 2004). Further, he described that purposive sampling is one that select sample based on the knowledge of a population and the purpose of the study that represents the population based on the ease of access and convinces of sampling. Based on this justification, the researcher purposefully selected Wolayta Sodo town, the capital of Wolayta Zone, as the case study area by using purposive sampling principle.

The contemporary structural plan of the town covers largely peri-urban areas and rural agricultural lands. These peri-urban kebeles predominantly rural in nature but it tend to be at the direct receiving end of urban expansion and development projects. Purposeful selection method from nineteen (19) administrative and eight (8) plan area kebeles or clusters five was selected. Such as Wadu, Fana, Mehal Gebeya, and Gola from plan area and Waraza Shohu kebele from town administrative area. The kebeles selection was based upon the frequency and practice of unavoidable land expropriation and land use conflicts; the effects of urban land use conflicts on social, economic, and environmental and the local government measures to prevent negative impacts of urban land use conflicts in expansion area of the town. In addition, it was checked by pilot study and field observation.

\subsection{Sampling Techniques and Sampling Size Determination}

In conducting this study, the researcher applied the field observation in selected kebeles and focus group discussion (FGD) method mainly focused in three kebele and collected various types of data related to the study under consideration. Primary data was collected using open and close-ended structure questionnaires and key informant interview with two selected local kebele managers, urban planners, a senior official, local inhabitants and municipal officials. Secondary data was collected from different data sources like Federal, Regional, zonal and Sodo town administration policy documents and reports, kebele or villages level offices annual report documents, and different publications (like books, journals, research reports and work papers and other internet-accessible documents).

The sample size in this study was determined by using the minimum sample size formula of Fowler(2001) and then adjusted for the total population of the study area by Cochran's sample size formula (Cochran, 1977)as shown below in equation 1 ;

$$
n^{\prime}=\frac{z^{2} * p * q}{(\sigma)^{2}}
$$

The researcher has been decided to take that true margin of error may exceed the acceptable margin of 5\% with confidence level $95 \%$ and estimated proportion of an attribute that was present in the population $\mathrm{p}=0.5$.

$$
n^{\prime}=\frac{(1.96)^{2} * 0.5 * 0.5}{(0.05)^{2}}=384
$$

In order to calculate the final sample size, the consideration of the total population of the study area. Therefore, 
Cochran's (1977) correct formula was used to calculate the final sample size in the study areas in equation 2;

$$
n_{0}=\frac{n^{\prime}}{1+\left(\frac{n^{\prime}}{N}\right)} \ldots
$$

Whereas $n_{0}$ is the sample size of the population; $n^{\prime}$ was the designated sample size and $N$ is the total household population in study area. The total number of population in the town is 137,529 and the researcher was carry out on five peri-urban kebele population was about 27,594 and the total household in the area was about 5000 (BoFED, 2016 abstract report).

$$
n_{0=} \frac{384}{1+\left(\frac{384}{5000}\right)}=\frac{384}{1.0768}=357
$$

The researcher delivered the support letter from HUST and the supplementary letter from the regional president office to the responsible organizations requesting permission to carry out research in the study areas. After that then proceeded to the respondents to make appointments to start distributing questionnaire and conducting interviews immediately.

\subsection{Data Collection Method and Instruments}

These study was collected both quantitative and qualitative data from primary and secondary sources. The secondary sources are literature review, reported conflict cases and base maps from the town. Moreover, the primary data collected from key informant interviews, focus group discussion and field observations managed by the researcher. The data collection was carried out by self-assisted and by three field assistants. Training of field assistants was done to avoid misinterpretation of questions and to ensure data quality (reliability and validity). Due to the sensitivity of urban land use conflicts, the assistants hired were selected based on maturity, above 30 years and with the certificate of good conduct in their kebeles.

The main sources of data and data collection instruments were used for this research both open and close ended questionnaire survey, focus group discussion (FGD) in each kebele three contain 3-5 peoples was using both structured and open-ended interview and direct field observations in the case study areas. Digital camera and sound recorder was used to collect the status of urban land use conflicts in expansion area and to capture pictures to show urban land use conflict effects in the area. The direct field observation instruments were base maps, images, and photographs. This made it possible to see the subjects as they appeared in their natural setting and analyzed the data.

\subsection{Data Analysis Tools and Presentation}

The data analysis tools were using Likert scales, MS-excel, and other relevant software. As Magsi, (2013) Likert scales one of the most commonly used analysis methodologies for measuring attitudes certainly in survey research methods. Likert (1932) states that the attitudinal object either positive or negative statements for each item, and they asked whether they: Strongly agree/Agree/Neither agree nor disagree/Disagree/Strongly disagree/do not know. On the other hand, the qualitative data of this research was analyzed by using computers in form of maps, photographs, illustrations and while spatial data, and by using GIS software in last three eras of the town expansion history or other relevant software.

The data analysis was applied for survey questionnaires, key informant interview, and FGD was coded and tabulating on the bases of data collections. Then, all primary and secondary data was analyzed and present by tables, charts, figures, and texts to facilitate data interpretation. Moreover, case narration of the household discussion was included to find out their feeling, opinion, and real problems of the households affected by urban land use conflicts in expansion area of the town. Before a questionnaire survey to collect data in the field, it was tested a pre-analysis of data done in first. This involves systematic organization of the raw data (from questionnaires, observation guides/check-lists, and interview schedules) into a manner that facilitated easy analysis.

\section{DATA FINDINGS, ANALYSIS AND SYNTHESIS}

\subsection{Urban Land Use Conflicts in Expansion Areas of Wolayta Sodo Town}

From filed observation and the questionnaires survey the respondents pointed out a number of land and land use conflicts has resulted in expansion areas of the town. Figure 5 describe the land and land use conflict types in the town such as land encroachment has reported that $85 \%$ occurred frequently and only $15 \%$ has reported nonoccurrence in the area. The boundary dispute in the area reported that $77 \%$ frequently and $23 \%$ nonoccurrence. Furthermore, land grabbing is also frequently take place in $67 \%$ and $34 \%$ reported nonoccurrence. At last but the major land use conflict was dumping of solid waste in open area emerged in $90 \%$ frequently and $10 \%$ non occurrence reported. Overall the land and land use conflict in the area was $83 \%$ frequently happened and $15 \%$ of least frequently. In general, $98 \%$ of land and land use conflict happened frequently and only $2 \%$ of respondents reported nonoccurrence in the area. Also, table 1 shows the passion of land and land use conflicts in the area.

Figure 2 and table 3 indicates that the most noticeable land and land use conflict in the peri-urban area was related to dumping solid waste on open space and land encroachment. The boundary dispute and land grabbing in 
the area was another critical problem due to the causes which have discussed in section of this chapter. Also, it indicated that in next shows that it needs focus to minimize the negative effects to the society. Therefore, the major urban land and land use conflicts in expansion area were described in detail in the following sections.

Table 3: Type of urban land use conflict in expansion areas of the town

\begin{tabular}{llcc}
\hline Types of Urban land use conflicts in expansion areas & Category & $\mathrm{N}$ & Percent (\%) \\
\hline Land Encroachment & Most Frequent & 150 & 42.0 \\
& Frequent & 74 & 20.7 \\
& Least Frequent & 81 & 22.7 \\
& Nonoccurrence & 52 & 14.6 \\
& Total & 357 & 100.0 \\
\hline Boundary dispute in the area & Most Frequent & 106 & 29.7 \\
& Frequent & 79 & 22.1 \\
& Least Frequent & 90 & 25.2 \\
& Nonoccurrence & 82 & 23.0 \\
& Total & 357 & 100.0 \\
\hline Land grabbing in the area & Most Frequent & 62 & 17.4 \\
& Frequent & 76 & 21.3 \\
& Least Frequent & 99 & 27.7 \\
& Nonoccurrence & 120 & 33.6 \\
& Total & 357 & 100.0 \\
\hline Solid waste disposal on open space & Most Frequent & 170 & 47.6 \\
& Frequent & 123 & 34.5 \\
& Least Frequent & 20 & 5.6 \\
& Nonoccurrence & 36 & 10.1 \\
& Total & 349 & 97.8 \\
\hline
\end{tabular}

Source: Field survey, 2017

Figure 2: Urban land use conflict in expansion area frequency (source: Field survey, 2017)

Urban land use conflict in expansion areas

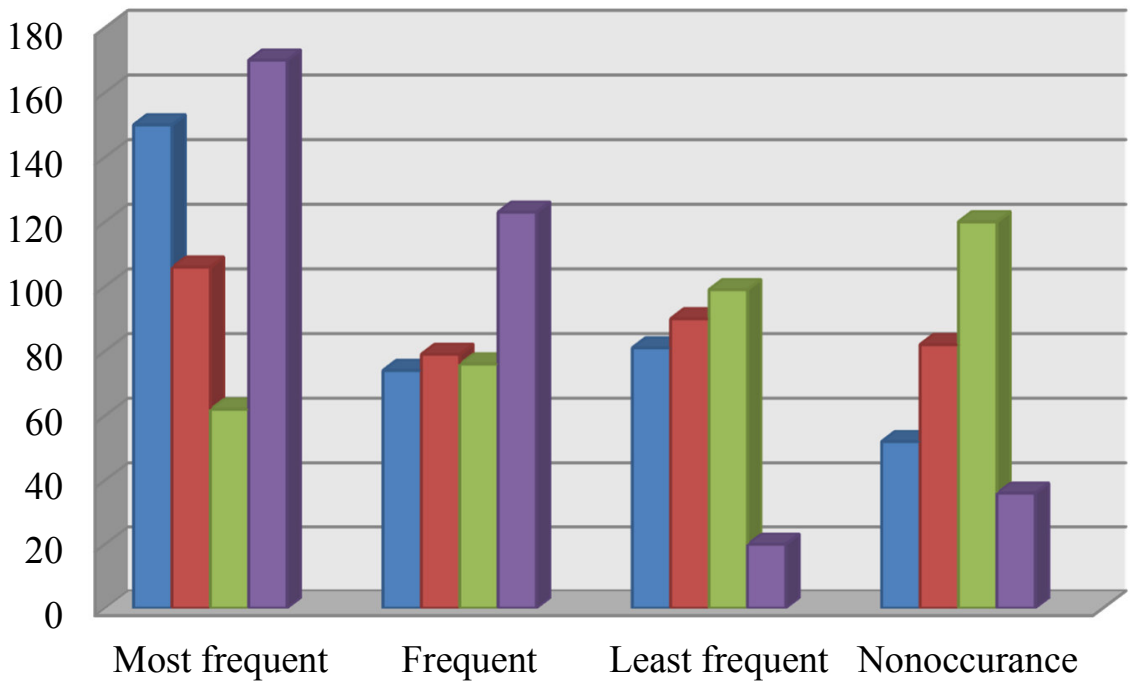

Land encroachment $\square$ Boundary dispute $\square$ Land grabbing $\square$ Dumping solid waste

\subsubsection{Disposal of solid waste on open spaces}

From field observation and mapping of the town up side of surrounded by mount Damota terrain. The flooding during the rainy season was a major problem in downstream local areas. Additionally, the study area has the lowest altitude within Sodo town. Whereas, it rains in Mount Damota area the flood water drains into Kalte River and Geneme/Beshir River which the solid waste ways toward the study area and to Sodo zuria and Humbo wereda kebeles. For example, in 2011 the solid waste from the town and rubbish from Wolayta Sod University in the area left more than two domestic animals dead, destroyed properties and left several sanitation problems to human being. Figure 6 shows that lack of waste disposal site and high accumulation of solid waste near to Fudene forest on open space can causes sanitation for human being and result loss of animal life. Also, it is perpetual conflict with the residential areas and great risk to residents. 


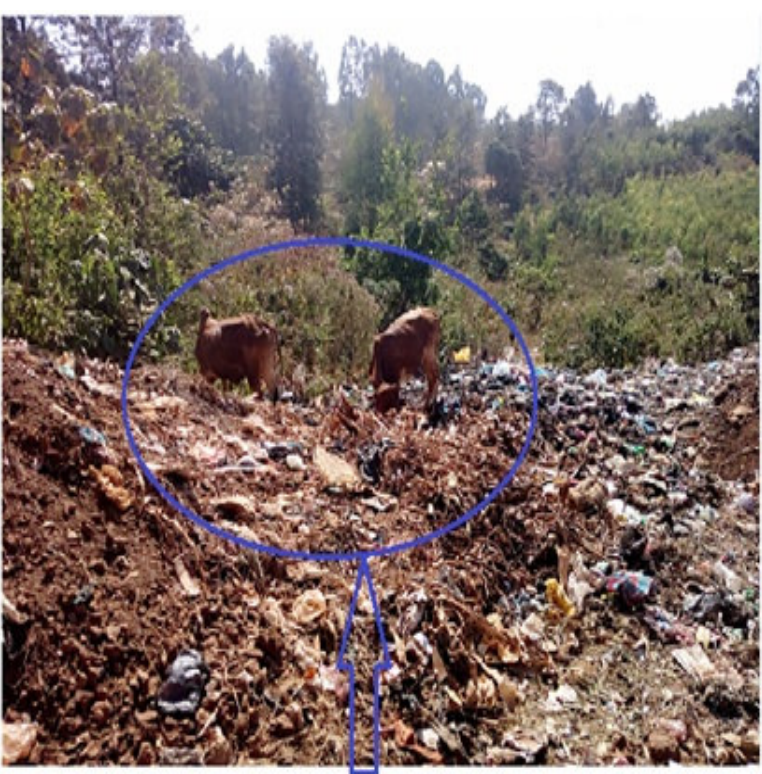

Animals grazing on open waste disposal site which can cause health problem

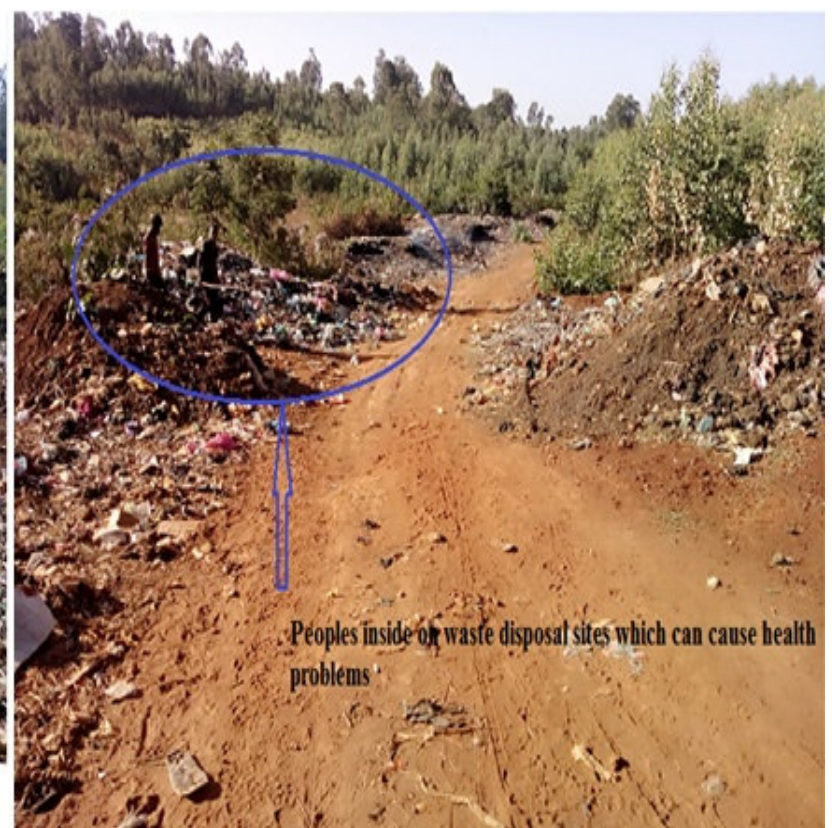

Figure 3: The solid waste disposal site near to Fudune forest area which cause sanitation problem (Source: Field observation, 2017)

\subsubsection{Degradation of access to roads}

From the interview, the majority of respondent referred to have road developments projects in the area. Figure 3 shows illegal dumping of soil on the highway and soil surface road reserves. This is not only blocking the roads but also make them impossible to cross during the rainy season and making traffic accident in the area. Excavated Black cotton soils at the time of setting outbuildings are as figure 4 dumped on empty spaces especially on riverbeds, road reserves, and unoccupied lands. Also, from field observation around Waraza Shohu kebele, the solid was dumped on the natural soil surface road and which was a problem during rainy season as well as the sanitation problem for road crossers. There should be designated areas, such as abandoned quarries, where such soils should be deposited. Developers should uphold soil dumping regulations and be compelled to allow the rules of the land. High penalties imposed and meted to those who flout such laws.

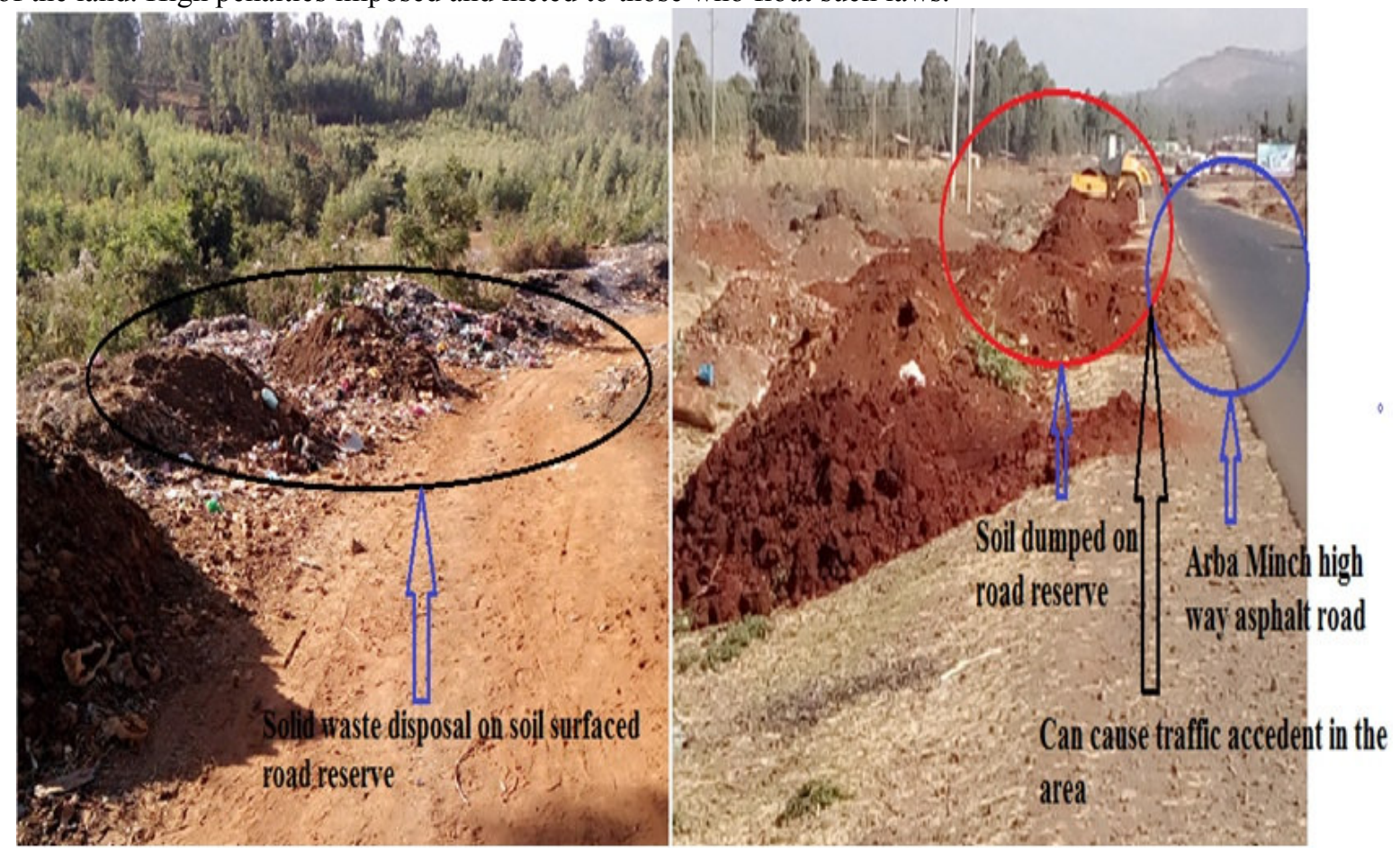

Figure 4: Soil dumped on road reserve (Source: Field survey, 2017)

\subsubsection{Land encroachment}

It is already known that the current urban expansion of urban center in Ethiopia in general and particularly in 
SNNPR tends to horizontal rather than vertical expansions. Hence, the expansion of the towns means a horizontal expansion of towns and it consumes the surrounding peri-urban agricultural lands. The main problem here lies between the high land demands for newcomers for residential and commercial activities and the landholder interests. Additionally, the supply of land for those activities by towns is not adequately managed for urban land uses. Hence, due to low supply of land, the encroachment of surrounding agricultural land has been taking place informally. Encroachments were reported during the questionnaires survey and from field observations. Likewise, boundary related conflicts were found to be frequent, with the area chief indicating that they are at least five cases per day reported to each kebele manager offices on weekly basis. Figure 5 shows that the stone placed in the middle of the road reserves endangering the Bajaj cycle. Also, the private properties encroach on road reserve and neighbor's properties causing social conflicts.

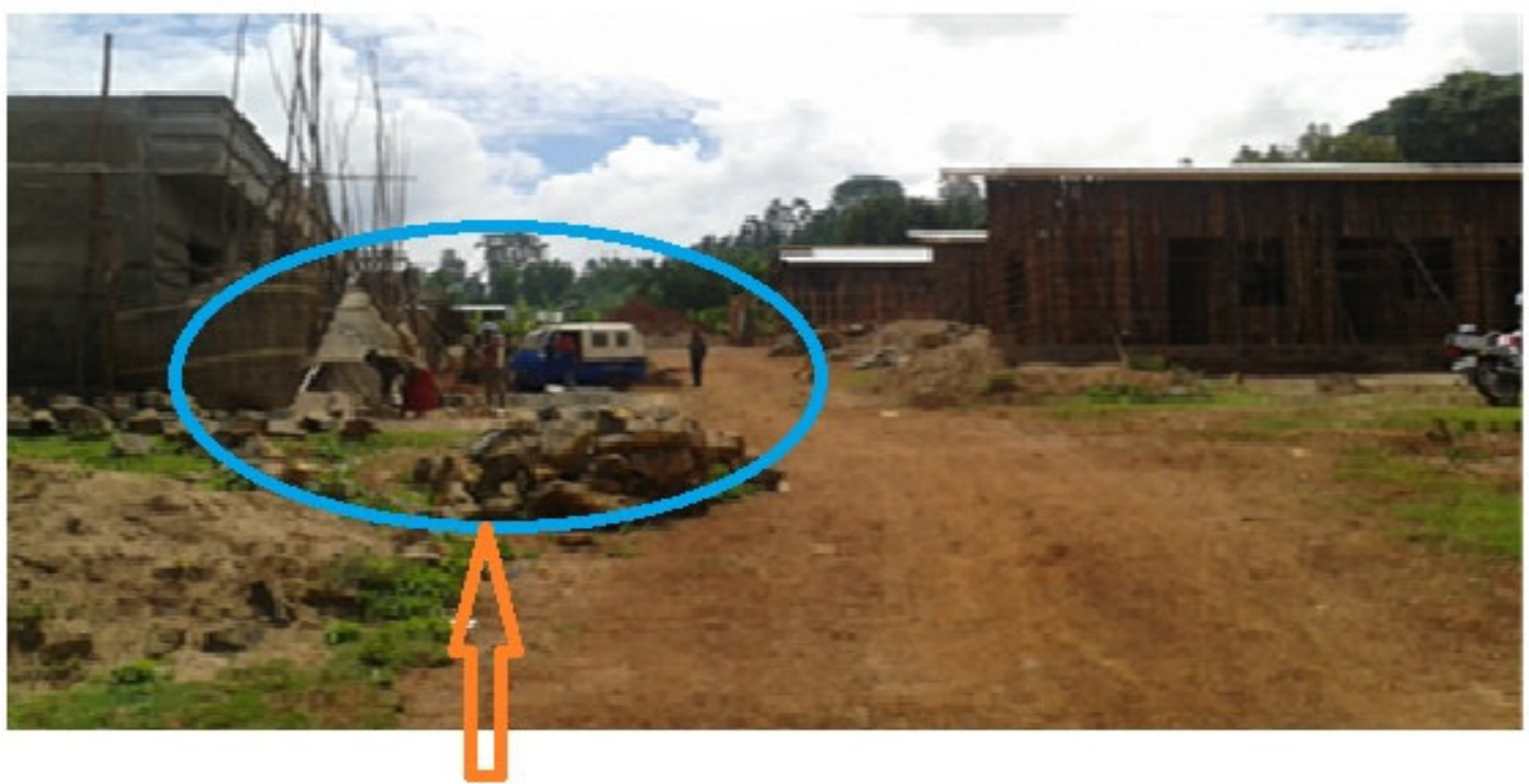

Road narrows as site development encroachment on it.

Figure 5: A caption on a boundary issue (Source: field survey, 2017)

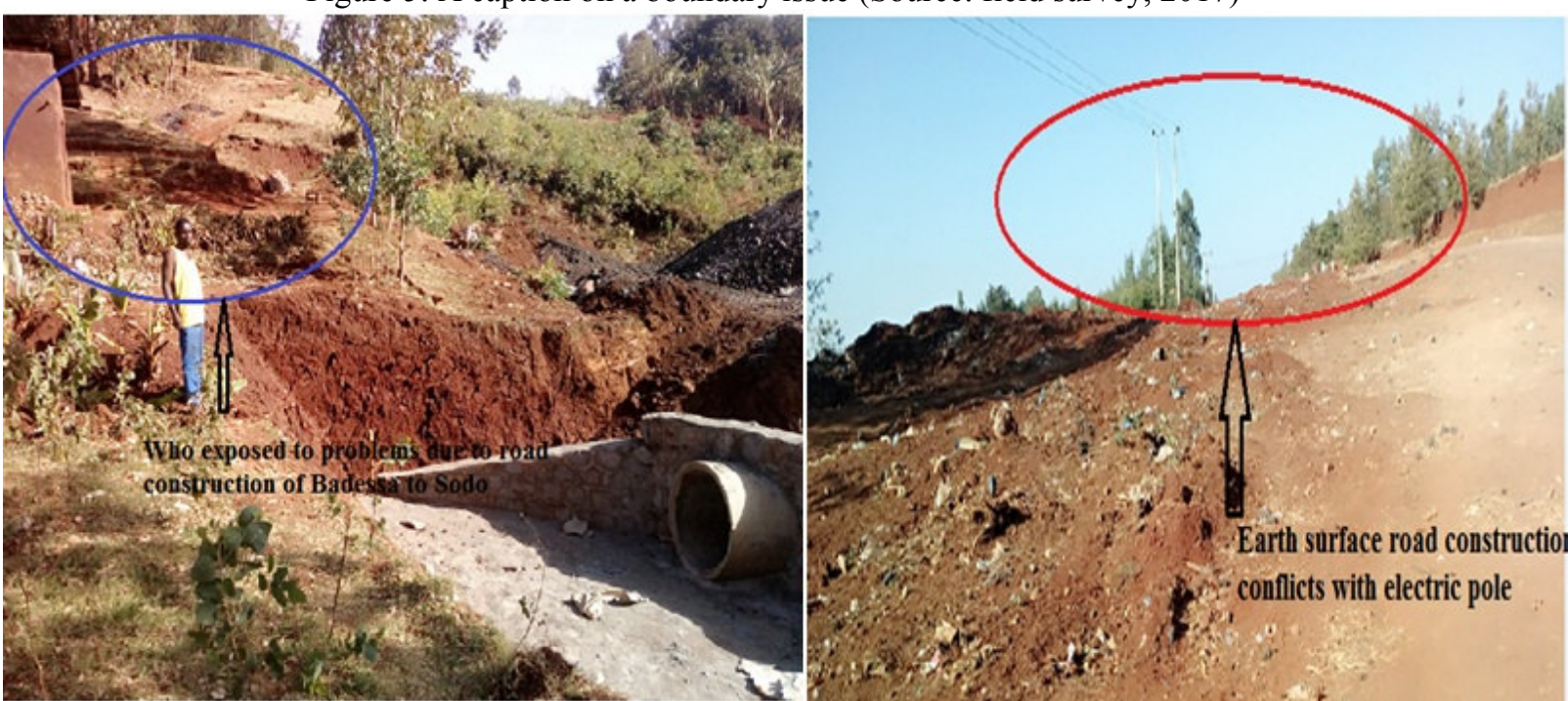

Figure 6: Encroachment of properties and services on road reserve (Source: Field survey, 2017)

The above figure 6 indicate the private property encroached by the road construction which is from Badessa to Sodo asphalt via Bitena and Morocho. It clearly shows the construction of road exposes him and his families to the problem even the way to communicate with his neighbours and his children's in fear to go outside. The second part of the picture also indicates the road construction encroach electric pole. Therefore, land encroachment was critical problem expansion areas of the town.

\subsubsection{Land usufruct right conflicts}

From focus group discussion and interview $89 \%$ of respondents revealed there was land usufruct right conflicts in 
the area due to inadequate compensation for their property and their children's right during land expropriations. As their view, the rural land administration and use proclamation No. 456/2005 recognizes their children's right inheritance of their family land but the urban land lease proclamation No. 721/2011, restricts this right. For example, before 2014 only the landholders have right to get alternative land sized $400 \mathrm{~m}^{2}$ and their children's does not have the inheritance right as stated in rural land administration and use regulation. On other hand, forcibly expropriation was another case of land ownership conflicts and negotiating the landholders for public purpose were revealed during the interview.

The local kebele leaders, the kebele managers and land management and development process experts of the study area indicated that they deal with at least two or three cases per week on matters related to double allocation, family issues on land succession where some family members exclude others during the sale of property. Moreover, the focus group discussion in three kebeles of landholders reveals that their children right was the source of conflict regard with land ownership. On the other hand, the land the landholders made forged certificate to get additional land and no adequate information to screening. However, the kebele social justice committee approved their legal status without critical evaluation and these documents recognized as a legal document in the municipality. For example, in Fana kebele since 2004 there were150 landholder children's cases around Agricultural College area unsolved problem in the kebele. Additionally, 32 households displaced in 2015 for $9^{\text {th }}$ lease land supply was only get alternative land without compensation. Due to this, reason 116 lease sites or plots did not construct with conflicts of landowner's. Moreover, in Fana kebele in 2005 and 2014 for Agricultural College expansion, 21 hectares and 74 household and their children 54 displaced but still, they were suffering. In near to Wolayta Sodo university the same case 128 households displaced from residential housing but still some of them suffering and did not compensate for their land use right. Even though, the formal court does not solve their cases in normal procedures. Therefore, some of the members have petitioned the official to appear before the local chief and explain the where about of ownership documents. They wanted the chief to guide them on the way forward. In his arbitration, the chief directed the parties to seek the services of a surveyor of which they agreed, though without legal documents the case is had to handle. Table 4 describe that the respondents from questionnaire survey were reported $77 \%$ of land use conflict due to the inheritance right. Table 2 indicates $77 \%$ of the urban land use conflict resulted due to lack of access to landholders and their children's as well as $59 \%$ was by forcibly expropriating their land in the area.

Table 4: Land use right conflicts in expansion area of Wolayta Sodo town

\begin{tabular}{llcc}
\hline Type of Land use right conflicts & Category & $\mathrm{N}$ & Percent (\%) \\
\hline Lack of access to landholders and their children's & Strongly Agree & 144 & 40.3 \\
& Agree & 130 & 36.4 \\
& Neutral & 25 & 7.0 \\
& Disagree & 50 & 14.0 \\
& Strongly Disagree & 8 & 2.2 \\
\hline Forcibly expropriating of their land & Total & 357 & 100.0 \\
& Strongly Agree & 146 & 40.9 \\
& Agree & 132 & 37.0 \\
& Neutral & 12 & 3.4 \\
& Disagree & 56 & 15.7 \\
\hline
\end{tabular}

Source: Field survey, 2017

\subsubsection{Environmental degradation based conflicts}

The respondents pointed out environmental based land use conflicts in the area. For example, $86 \%$ agreed on not accompanying environmental protection and $77 \%$ of the respondent revealed urban expansion degrade environmental beauty. Figure 5 indicates the land can be congested with various land uses. The solid waste dumped near to Kalte River and residential area in Waraza Shohu kebele. The Kalte River generates foul smell that pollutes the air and it can causes health problem to the society. The other critical problem is Kalte River water flow to downward and the solid waste from the town and disposed on lower catchment area and it makes create sanitation problems to the human being and animals. In addition, it pollutes the environment and degrades its beauty. As a result, there was a loss of animal life and health problem for the human being. The environmental degradation which affected by the disposal of solid waste on open space and environmental beauty degradation, as shown in Figure 5. Moreover, the questionnaire respondent and interview with the landholder of peri-urban area was revealed that most of the land which was set aside for public use was in private ownership. This hinders the provision of public services such as schools and health-causing disagreement between development densities and service provision, hence inadequacies in the provision of services like physical and social infrastructure resulting in human suffering. 
Table 5: Environmental based urban land use conflicts

\begin{tabular}{llrr}
\hline Environmental degradation & Category & Percent $(\%)$ \\
\hline Not accompanied environmental protection & Strongly Agree & 127 & 35.6 \\
& Agree & 178 & 49.9 \\
& Neutral & 11 & 3.1 \\
& Disagree & 26 & 7.3 \\
& Strongly Disagree & 15 & 4.2 \\
\hline Degradation of environmental beauties and values & Total & 357 & 100.0 \\
& Strongly Agree & 157 & 44.0 \\
& Agree & 117 & 32.8 \\
& Neutral & 18 & 5.0 \\
& Disagree & 49 & 13.7 \\
& Strongly Disagree & 16 & 4.5 \\
& Total & 357 & 100.0 \\
\hline
\end{tabular}

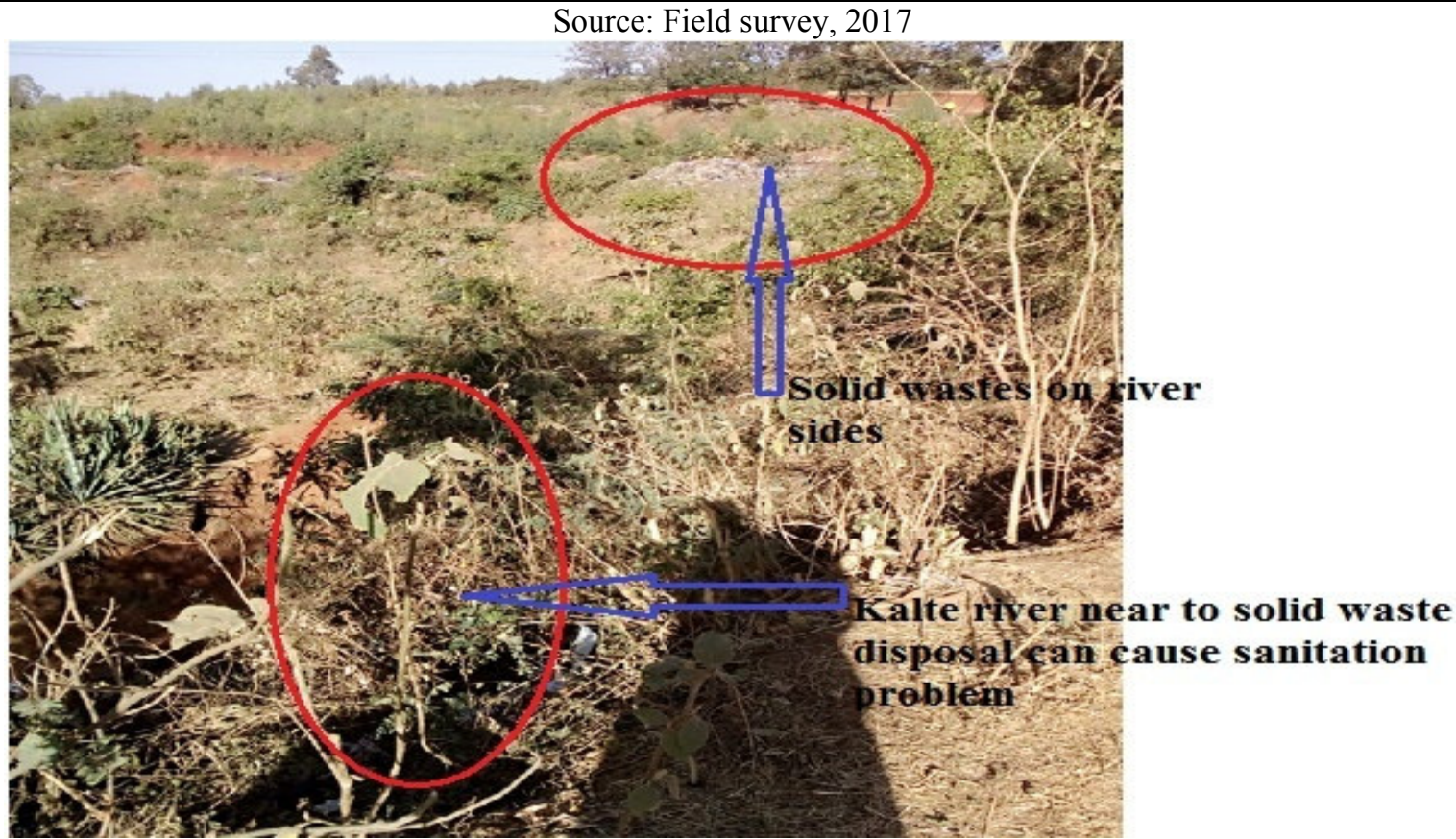

Figure 7: Environmental concern (Source: field survey, 2017)

\subsection{Causes of Urban Land Use Conflicts in Expansion Areas of Wolayta Sodo Town}

Urban land and land use conflicts in peri-urban areas of the town were caused by different factors. The major factors were inadequate compensation for the property of landholders and rehabilitation, lack of land ownership documents, double allocation of single plots and limited supply of the urban land were the major problems in the area. Additionally, the respondents indicated the causes of urban land use conflicts as in table 6 described that inadequate compensation and their children's right about $77 \%$, poor land governance $75 \%$, lack of ownership documents $72 \%$, forcibly expropriating $59 \%$ and double allocation of single urban plots to more than one person. In general, loss land use right and environmental degradation is the major causes for the conflict in the area. Therefore, the major causes of urban land use conflicts in the area discussed in detail as the following:- 


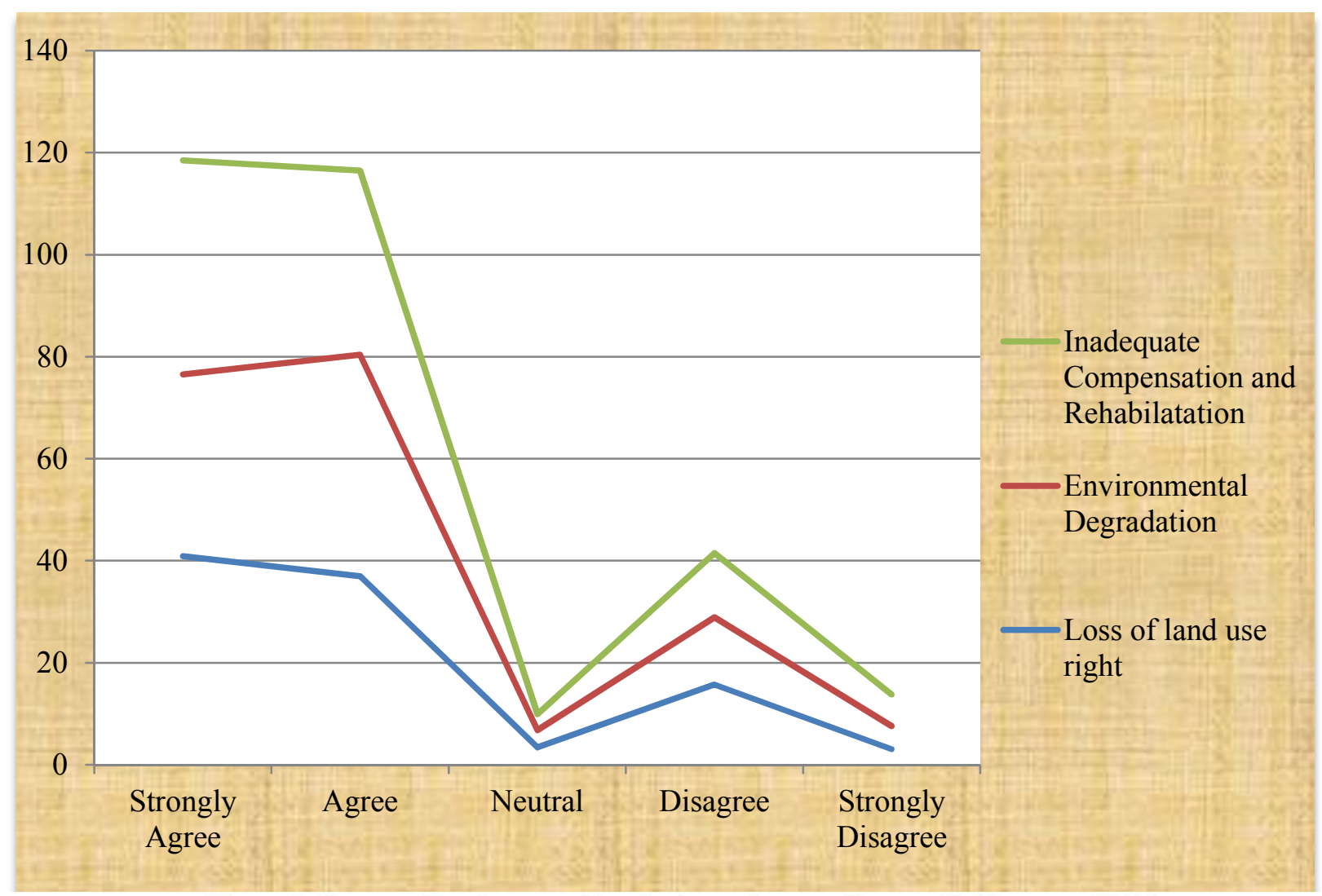

Figure 8: Causes of land use conflicts in the study area (Source: Field survey, 2017)

Also, table 8 show that the frequency and type of urban land use conflicts in Wolayta Sodo town as questionnaire survey respondents. According to respondents $78 \%$ of land use conflicts related to loss of land use or ownership right, $79 \%$ reported that environmental degradation and $78 \%$ due to inadequate compensation and loss of their children's inheritance right.

Table 6: Causes of land use conflicts resulted in the town

\begin{tabular}{|c|c|c|c|}
\hline Land Use conflicts & Category & $\mathrm{N}$ & Frequency $(\%)$ \\
\hline \multirow{6}{*}{ Loss of land use right } & Strongly Agree & 146 & 40.9 \\
\hline & Agree & 132 & 37 \\
\hline & Neutral & 12 & 3.4 \\
\hline & Disagree & 56 & 15.7 \\
\hline & Strongly Disagree & 11 & 3.1 \\
\hline & Total & 357 & 100 \\
\hline \multirow[t]{6}{*}{ Environmental degradation } & Strongly Agree & 127 & 35.6 \\
\hline & Agree & 155 & 43.4 \\
\hline & Neutral & 12 & 3.4 \\
\hline & Disagree & 47 & 13.2 \\
\hline & Strongly Disagree & 16 & 4.5 \\
\hline & Total & 357 & 100 \\
\hline \multirow{6}{*}{$\begin{array}{l}\text { Inadequate compensation and } \\
\text { rehabilitation related land use } \\
\text { conflicts }\end{array}$} & Strongly Agree & 150 & 42 \\
\hline & Agree & 129 & 36.1 \\
\hline & Neutral & 11 & 3.1 \\
\hline & Disagree & 45 & 12.6 \\
\hline & Strongly Disagree & 22 & 6.2 \\
\hline & Total & 357 & 100 \\
\hline
\end{tabular}

\subsubsection{Lack of land ownership documents}

Ownership certificates for land properties were not repossessed to the majority of urban-based housing units and other buildings including those constructed with building permits provided by municipalities. However, SNNPR Urban Development and Housing Bureau abstract report in (2015) around 1768 illegal built housing units were demolished in a time when the administrative boundary expands from 3500 hectares to 9600 hectares in the region. 
Even though the housing unit was demolished but the built lands were not confiscated as, it stated in urban land lease regulations. As the report, unplanned land encroachments and residential house unit construction were another factor that contributes to the rapid urban expansion mostly squatter has not controlled in the region especially in peri-urban areas. Therefore, the main cause for an urban land use conflict in the region was a lack of legal land ownership documents for their land in the cities/towns.

Furthermore, from the questionnaire survey, focus group discussion and key informant interview the causes of an urban land use conflicts were a lack of ownership documents in peri-urban areas of the town was prevalent. Table 7 shows that that the majority $(95.8 \%)$ of the respondent owns the land they live and figure 8 shows that $36.4 \%$ of them purchased the land while only $23.8 \%$ inherited the land they reside.

Table 7: Ownership of the land of residence

Do you own the land on which your HH resides?

\begin{tabular}{lll}
\hline Ownership (Y/N) & $\mathrm{N}$ & Frequency (\%) \\
\hline Yes & 342 & 95.8 \\
No & 15 & 4.2 \\
\hline Total & 357 & 100 \\
\hline \multicolumn{3}{r}{ Source: Field survey, 2017}
\end{tabular}

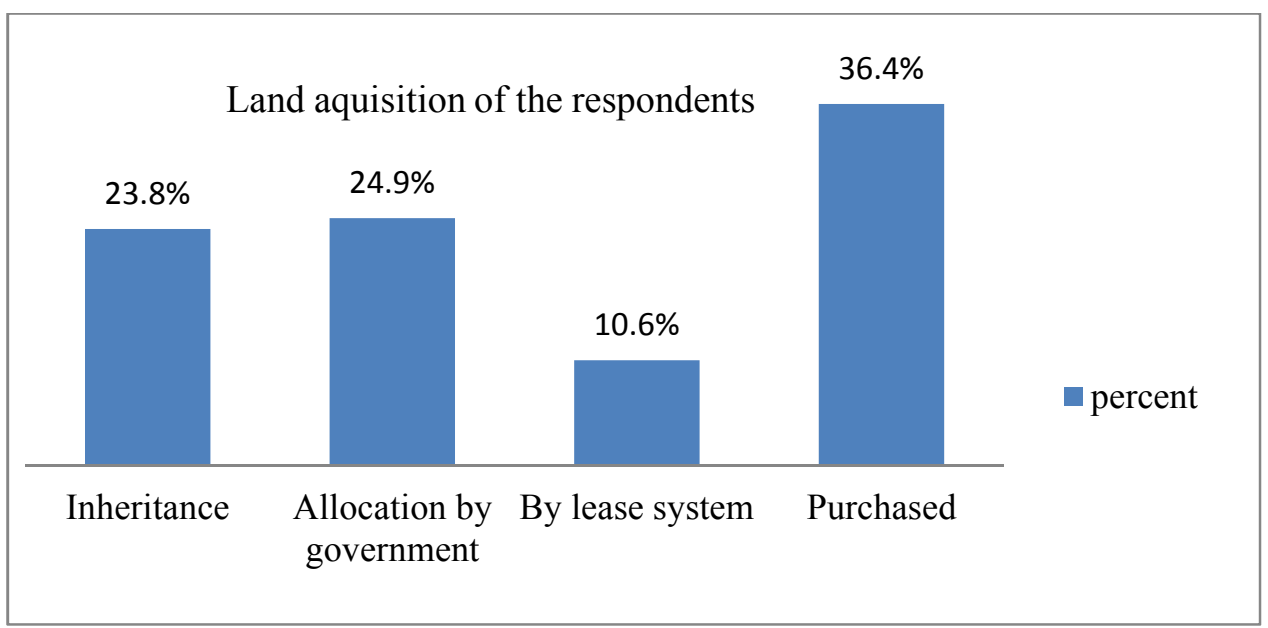

Figure 9: Method of acquisition of land owned (Source: Field survey, 2017)

It is a matter of concern that though $95.8 \%$ of the respondents own land, $26.1 \%$ of them do not have urban land lease agreement or legal title to their land in peri-urban areas. However, table 7 indicates that only $13.2 \%$ have legal title deeds/lease agreement and $58 \%$ have a rural land use title deed/usufruct right. In this case, $42 \%$ of respondent do not have the legal right to their land during expropriation has resulted the conflicts break out.

As key informant interview of local farmers and kebele leaders, the lack of ownership document resulted on land use conflicts in urban expansion areas sometimes was ending up with conflicts over aspiration and legalities occurring on that land. Due to these difference and conflicts on peri-urban land brings illegal or squatter settlements, land speculators mainly manipulate the land and the medium and lower income groups of people who failed to afford the high lease price moved from center to peripheral area result in a conflict of land uses.

On the other hand, as their view to the town administration will not remain idle when these illegal housing units were constructed on peri-urban and land grabbing has taken place. Then, the conflicts begin here as an urban authority either successes or demolish illegally built houses and grabbed lands or prevent squatter settlements ahead of construction. As a result, serious conflict and scuffles occur between the builders, speculators and the town administration.

The study pointed out that in 2014 there was 11.45 hectare and in 2015 there were 41 hectares occupied by informal settlement in Wolayta Sodo town recorded but the number of informal housing unit data not unavailable. Owners are in possession of ownership documents from unregistered sources, which cannot replace the need for a statutory ownership certificate. From the above data, we understand that lack of land ownership document and the illegally built area was the major causes for urban land use conflicts.

\subsubsection{Double allocation of urban plots}

From the questionnaire survey 55\% of respondent reported urban land conflicts caused by double allocation of single urban land plots to more than one person and also from focus group discussion $90 \%$ in Fana, $85 \%$ of Wadu and $74 \%$ of Gola kebeleswere reported the double allocation of plots was source of urban land conflict in the area. For example, in Fana kebele three villages (mender) such as College, Womba and Gendebareported 6 cases in 2014, 24 cases in 2015 and 57 cases in 2016 double allocation have reported in. Regional Urban Development and 
Housing Bureau, report (2016) in Wolayta Sodo town the double allocations of urban site plan provided to more than one person on single plots were frequent and after complain about their rights in court it was managed. This indicates that the illegality conflict with legality in the town. The subdivisions have no approval from the planning department and do not conform to the urban structural planning. Such resultant land development has no legal backing and hence prone to human abuse such as double selling of the same properties to different buyers, and conflict in boundary location of the said parcels.

Table 8: Ownership documents possessed by respondents

\begin{tabular}{lll}
\hline \multicolumn{3}{c}{ Land ownership documents possessed } \\
\hline Ownership document(Y/N) & $\mathrm{N}$ & Frequency (\%) \\
\hline Usufruct right & 207 & 58 \\
Lease agreement & 47 & 13.2 \\
Temporary occupation license & 4 & 1.1 \\
Company certificate & 6 & 1.7 \\
No document & 93 & 26.1 \\
Total & 357 & 100 \\
\hline
\end{tabular}

\subsubsection{Non-implementation of planning regulations}

Source: Field survey, 2017

The study conducted in peri-urban areas of Wolayta Sodo town either the cluster or kebeles in plan or administrative areas. The informality, building plans cannot be approved due to lack of legal ownership documents are available. Most of the developments have taken place with the full knowledge of the authorities who seem to have no powers in enforcing law and order. City planning officers usually play hide and seek game with developers encouraging illegal site developments to go on unabated. Due to these loopholes, more illegal developments carried out without approvals hence non-adherent to development regulator.

Regularization programs for both land subdivision and developments, which have already taken place in the town but if without the approval then the municipality needs to demolish the built houses. Owners are being encouraged to submit the plans for approvals using the original mother titles and development plans. This is a way of legalizing the informal land subdivision and developments, however, most of the developments cannot meet the required standards. Some cases may never be approved such as those with multiple uses on small parcels of land where there are higher levels of land use conflict.

\subsubsection{Little or no professional policing}

Urban plan preparation and implementation in the study area does not equip with professional expertise. Due to this urban plan, preparation does not depend on detail socio-economic and spatial data. However, it focusing on engulfing peri-urban areas land into urban centers administratively. The peri-urban area administratively included in the town but the urban land use plan does not prepared and implemented appropriately. Also, Lucy, (2014) described that the professional ethics and policing was found to be wanting. If ethics are supported the rate of land grabbing would be few. Professional policing would also mitigate the levels of illegal subdivision and planning implementation procedures.

\subsubsection{Inadequate planning awareness}

From the focus group discussion of three kebele, $89 \%$ of ignorance to their opinion and lack of knowledge to the local chief on land matters was a major concern in the area. It prevents prospective land buyers from carrying out a legal search of the land they want to buyand thus exposed to fraud. Furthermore, according to key informant interview of the Zone Urban Development and Housing department experts, most of the urban land use conflict causing problems in the town was no discussion and awareness creation with local landholders head off trying to get the urban land. In this case, tension develops between the municipality and the landholders whose land has been expropriated. The second main problem regarding the valuation of a property is that the inadequate or without compensation to expropriate their land by convincing or lobby the landholders. In this case, the landholder does not obey they were sanctioned and the complaint considered as buck of social change and legal institutions. As the result, the complaints were assumed as opposing the development of the community in the area. Due to this, they develop silence grievance because of legal and illegal sanctions reported by the landowners.

\subsubsection{Compensation and Rehabilitation Causes for Land Use Conflicts in the Area}

Since urban expansion, not only significant wrongdoings associated with the land acquisition, compensation and resettlement plans were observed, but no adequate mitigation measures have been handled. The aim of urban expansion as the policy document in the country was to foster sustainable development in urban areas. In this regards the urban public authority in expansion area has failed due to following shortcomings: counseling with affected communities during planning and execution of the development plan; adequacy of the land and their property valuation, assessment and disbursement of the compensation in the area; illegitimate alternative or resettlement site selection and institutional arrangement performances were reported. Table 9, indicates that the $54 \%$ respondent expropriated their land for urban expansion and 30\% of them responded fairly compensated but $39 \%$ unsatisfied by the compensation and $44 \%$ were not responded. 
Table 9: Your land has been expropriated for urban expansion

\begin{tabular}{lll}
\hline Your land expropriated & $\mathrm{N}$ & Frequency Percent \\
\hline Yes & 194 & 54.3 \\
No & 163 & 45.7 \\
\hline Total & 357 & 100 \\
\hline
\end{tabular}

Source: Field survey, 2017

From the key informant and FGD, 97\% agreed on the main problem on expropriating land in peri-urban areas was disagreed over the compensation paid for their property of the landholders. Actually, the valuation does not follow the constitutional guarantee and the land expropriation and compensation proclamation 455/2005 and regulation of council of ministers No. 135/2007 in the area. Additionally, maltreatments over the compensation valuation were an important factor for conflicting issues in peri-urban areas. However, the land acquisitions and delivered for different development projects in the study area was not supported by regional directives and regulation. Furthermore, as focus group discussion in three kebeles; even if the federal government proclamation itself might not be considered due to ignorance, negligence and emergencies (without planned activities but only focusing on development agenda). As a result, no further ideas and plans for resettlement of displaced landholders and no measures to prevent shortcoming of land expropriation.

So far, as focus group discussions in three kebeles such as Wadu, Fana and Gola with expropriated landholders revealed that first they do not have time to complain about unfair compensation regard to their property as rules and regulation; secondly the valuated file (document) of their property has disappeared from appointed committee members or municipality without compensation paid for them. On the other hand, the landholder complains about his/her property right immediately he/she will be in jail up to the launching of the project. As a person whose land expropriated in Wadu kebele explanation, he complained about his right and he would be detained for two weeks. Furthermore, the other respondent in the same kebele prevailed that the municipality expert does not informed to landholders to valuate their property. The other problem is without valuation and free information the road has swept with their property in Wadu kebele. As their view in Wadu kebele landholders, the compensation valuation method and the detention process has reported was based on legal ground and influenced by government officials in the kebele. Similarly, from Gola kebele key informant interview the compensation valuation system was under the influence of political leaders and the appointed committee members does not follow rules and regulations. Even if, in the absence of the landholders the valuation had been done on their property and at the end, he/she was enforced to accept without their participation the valuated price for their property.

Additionally, as key informant interview and focus group discussion of Gola kebele landholders report there was forcible expropriation of their land without compensation. Additionally, the farmers displaced with their grievance if they refuse to accept the decision the municipality they forcibly displaced. For example, $94 \%$ of FGD discussion has reported the valuation committee members influenced by government officials and they did not follow rules and regulations. However, the proclamation No. 455/2005 gives the mandate for wereda and town administration to inform the local farmers by legal letter for their land expropriation. Sometimes they acquaint by meeting for local kebele leaders and at the same time compensation valuation committee started the process. Because of this, the local dwellers does not have time to be ready psychological and to collect the property.

The other conflicting issue in the study area related to compensation and resettlement was that the federal government project like road construction, University construction, and other projects followed the rules regulations. For example, as a key informant, the municipality valuates for one-year period of time production but the federal government valuate for ten years according to rules and regulation. Therefore, inadequate compensation, lack of adequate land use policy, and planning and lack of regional regulations and directives to guide during the urban expansion and compensation valuation is critical cause for land use conflicting in the area.

Table 10: Fair Compensation Package for Expropriated Land

\begin{tabular}{l|l|l}
\hline Fair compensation for expropriated land & $\mathrm{N}$ & Frequency (\%) \\
\hline Yes & 61 & 17.1 \\
No & 140 & 39.2 \\
N/A & 156 & 43.7 \\
\hline Total & 357 & 100 \\
\hline \multicolumn{2}{r}{}
\end{tabular}

The above table shows that the satisfaction of fair compensation was a serious problem and causing urban land use conflicts in the area. Moreover, from the questionnaire survey, $59 \%$ of respondent reported that their land could be forcible expropriated.

\subsection{The Effects of Urban Land Use Conflicts}

Positive impacts due to urban expansions for peri-urban area were they exercise modern life and they get infrastructure accessibility. However, urban expansion socially brought uncharacteristic or strange conditions for 
peri-urban local farmers. The main problems related with this were the livelihood and unemployment problems. Additionally, the other problem due to urban expansion was the landholders does not support economically and does not consider their rehabilitation. Either due to lack of skill in financial management, the compensation money they deposit in the bank or they defalcate or spend the money. Furthermore, the landholders do not supported and engaged economically in a sustainable way for their future life. Additionally, before land expropriation, there was no strategic plan for the displaced landholder rehabilitation and they do not have the training to develop their business plan and to manage the compensation money. Due to this even if they got compensation either they put money in the bank to deposit or they expend because of poor management skill. In general, during urban expansion, the consideration was only to get urban land. In this case, the urban expansion was source of a dread in the periurban area.

Environmental effects of urban land use conflicts in expansion area were deforestation, flooding, solid waste disposal etc. For example, as Wolayta Sodo experience the town lies on foot of mount Damota and two rivers Kalte and Beshir/Geneme was flowing with huge solid waste and can affect the downward society. The Kalte river flow to Humbo wereda kebeles and Beshir/Geneme River flows to Sodo zuria wereda kebeles. In addition, solid waste management in the area was a great problem for so many years. Because of this, solid waste disposed on open space near to Fudune forests the exposed farmers and animals to sanitation and health problems. The solid waste management in the town has effects on peri-urban areas land use like polluting underground water for in the town which is potable water like Likmise and likewise.

Land encroachments and ownership conflicts have resulted into lengthy court cases with a waste of finance and time as found out during this study. These also cause strained neighborhood relationships, underdevelopment and delayed justice in the area.

Illegal dumping of excavated black/red soils and encroachment causing pain and frustration to the residents has not spared access roads. Moreover, the solid waste which dumped on road reserve caused both traffic accident and health problems.

The flourishing urban expansion related to inadequate compensation and their children's right handling way expose the residence to conflicts with little legal redress especially in cases of ownership conflicts. Sustainable development cannot be achieved where planning controls are not implemented.

Lack of implementation of land use controls has greatly affected the area and it would be impossible to have sustainable developments thus resulting to pollution in low standards of living. This is seen in the rampant distribution of incompatible land uses is common which in itself affect the whole wellbeing of the society.

\subsection{Local Government Measures to prevent Urban Land Use conflicts}

Urban Development policy and strategy in the country put directly the urban dwellers' issue (beneficiary) according to the constitutions and the proclamations related to land laws. The Federal Government rules and regulation constitution focus on all property rights. However, the urban land regulations and rules focus on plan area whereas it does not threaten the peri-urban dwellers. Furthermore, as a regional government the in Amhara and Tigrai regional states and in Addis Ababa and Dire Dawa city administration urban land issue proclaimed in their regulation and directives based on Federal Proclamation. Southern Nation Nationalities and Peoples Regions and Oromia regional state directly implement the Federal proclamation No. 455/2005 as their regulations and directives.

According to key informant interview, the local government awareness creations and prevention measure for the urban land use conflicts in the study area was stated as the following. The first problem was no discussion and awareness creation for the landowners ahead of trying to get their land. In this case, tension develops between town municipality and the farmers whose land to be expropriated. The second problem regarding valuation of the property that the committee members influenced by government officials to valuate the property with low or without compensation. Therefore, silence grievance because of social and legal sanction. These indicate that the urban expansion problems were not anticipated early enough and the municipality was not at all prepared for the eventuality of compensation payments. In the early days of urban expansion, most landholders were left uncompensated. The problem is legal and financial. The operational and structural land use conflicts prevention and resolution methods are open ended in the study areas.From the above data an urban land use conflicts increasing in the alarming rate and it needs focus and most of the land-use disputes arise therefore from the personal interests and the weakness of structural prevention method.

\section{CONCLUSION and RECOMMENDATION}

\subsection{Conclusion}

Urban expansion in the peri-urban area is new development agenda for the dwellers and actually conflicting with their lifestyle and the land uses. The aim of this thesis was to contribute to the resolution and prevention of urban land use conflict in Ethiopia, especially in Wolayta Sodo town.

This study found out that about $95.8 \%$ out of all respondents own land and from which $36.4 \%$ purchased 
urban land illegally. Also, the findings of the study show that the major urban land and land use conflict in expansion area were the solid waste disposal related $90 \%$, land encroachment $85 \%$, boundary dispute $77 \%$, and land grabbing is $67 \%$ happened frequently. The major causes also in the area were inadequate compensation and their children's heritance right (77\%), poor land governance $(75 \%)$, lack of land ownership documents $(72 \%)$, forcibly expropriating their land for urban expansion (59\%) respectively. These have led to informal land transactions where there is no guarantee of land tenure and lack land ownership documents. The other causes are inadequate planning; non-implementation of planning regulations, and soil dumping sites, which worsened the issue of urban land use conflicts. Moreover, there is little or no professional policing, inadequate planning awareness and double allocation of single urban plots to more than one person also indicated in the findings. Also, the valuation of their property and land does not follow the constitutional guarantee and the land expropriation and compensation laws in the area. Key informant interview revealed that about 1768 illegal built house unit demolished in the region in 2013 and from the document review 11.45 hectares land has encroached land was found in Wolayta Sodo town at the same time. Furthermore, the study has revealed that the rise in population will increase in demands on urban land uses like infrastructural developments, high demand on residential area, and social services are lead to conflict of land use. Thus urban land use conflicts were increased as the pressure increases on the land if preventive measures did not take with respect to conflict sensitivity. Additionally, urban expansion socially brought uncharacteristic or strange conditions for peri-urban local farmers. The results also supported by the literature on increasing land use conflicts in developing countries.

\subsection{Recommendations}

This study has revealed several critical urban land and land use issues that need urgent policy attention in the country as well as in the town. Therefore, the following recommendation forwarded:

In general as a country no land use policy and land use planning rules and regulation either in rural areas or in urban centers. Whereas urban centers regulated by local development structural plan as land use policy. As SNNPR region there was no urban land regulation and directive for implementation of compensation based on federal proclamation and council of ministers regulation. Though policies exist in land use issues need to be readdressed because of the case observed in the study that the people are not responsive to the laid down periurban land laws and regulations. Consequently, the improving land administration institutions and establishing an independent peri - urban land administration unit to minimize the negative impacts of urban land use conflicts.

The other policy areas indicated in the study are incorporating peri - urban land use planning and livelihood issues as a priority agenda; as result, public sensitization programs should be initiated especially by the professional bodies, inclusive land development tool, and avoiding aggressive measures and moving towards formalization/regularization. Promotion of social integrity would greatly improve the development of the study area as well as achieve a sustainable development.

Non-implementation of rules and regulation governing compensation and land expropriation shall be enforcing to solve the problem. Processes of land subdivision, land transactions, boundary re-establishments and development procedures have also adhere to minimize the impacts. These would result to minimization of urban land use conflicts in Wolayta Sodo town and optimization of developments in social, political and economic dimensions while taking care of the environment.

\section{ACKNOWLEDGEMENTS}

I wish many thanks to Almighty Gods for his care, blessing, and grace that has enabled me to get this far.

I acknowledge the tremendous contributions that various institutions and individuals have rendered in order to make this academic dreams a reality.

First, I would like to extend my sincere gratitude to my supervisor, Professor Shukui Tan for his thorough review, continuous advice and unreserved assistance from early title selection to the final write-up of this thesis. I would like to extend my thanks to Tsegaye G/Hiwot PhD student in Civil Engineering department at HUST and Bereket Roba who is lecturer at HU for their help technically and reading material support in developing my research work.

I wish to highly extend my genuine appreciation to my wife W/ro Wubalem Zegeye and my daughter Bama and Adonias Milkias for their never-ending prayer and scarification of their lovely time throughout my study and for their tolerance. Further, I would like thank all my families, especially to my mother Askalech Chanko and my mother in law Wosene Darota for their prayer and encouragement during my study.

I take this opportunity to express my thankfulness in particularly for the institutions Wolayta Zone Youth Federation leaders, South Ethiopia Youth Association leaders, and SNNPRs Rural Job opportunity Agency leaders and SEPDM quarters staffs for their material and moral support during my thesis work. Finally, yet importantly, I would like to thank all respondents who participated in filling the questionnaire, providing supplementary documents and all other support during data collection. 


\section{REFERENCES}

AchamyelehGashu Adam(2009): Urbanization and the Struggle for Land in the Peri-Urban Areas of Ethiopia, Bahir Dar University, Ethiopia.

AchamyelehGashu Adam(2014):Peri-urban land rights in the era of urbanization in Ethiopia: A property rights approach, African Review of Economics and Finance Vol. 6, No. 1.

AckermanAlice (2003): The Idea and Practice of Conflict Prevention, Journal of Peace Research, vol. 40, no 3.

Anna Locke and Giles Henley, (2016):Urbanization, land and property rights, the need to refocus attention, shaping policy for development www.odi.org.

Anna M. Hersperger, Cristian IOJA, Frederick Steiner and ConstantinaAlina Tudor (2015): Comprehensive Consideration of conflicts in the land use planning process: A Conceptual Contribution, Carpathian Journal of Earth and Environmental Sciences, Vol. 10, No 4.

AshenafiGetachewAnulo (2015): The Factors Contributing for the Expansion of Informal Settlements in Hossana Town, Southern Ethiopia, Addis Ababa University, School of Graduate Studies, Department of Public Administration and Development Management, Master Thesis, Addis Ababa Ethiopia.

Cochran (1977): Sampling techniques, New York: John Wiley and Son.

Crane, W., Sandwith, T., McGregor, E. and Young, A., (2009):Where conservation and community coincide: A human rights approach to conservation and development in the Cape Floristic region, South Africa. In (eds.) Campese, J., Sunderland, T., Greiber, T., Oviedo, G., Rights-based approaches: Exploring issues and opportunities for conservation. CIFOR and IUCN. Bogor, Indonesia.

Central Statistical Authority (CSA,2013):Population Projection of Ethiopia for All Regions at Woreda Level from 2014-2017, Addis Ababa, Ethiopia.

Central Statistical Authority (CSA,2015): Ethiopia Statistical Abstract, Central Statistical Authority, Addis Ababa, Ethiopia.

Darly, S. and Torre, A., (2013):Land-use conflicts and the sharing of resources between urban and agricultural activities in the Greater Paris Region, Results based on information provided by the daily regional press. In: Noronha Vaz, T., Leeuwen, V.E., Nijkamp, P. (Eds.) Towns in a rural world. Ashgate, London.

FDRE (2005): Federal Democratic Republic of Ethiopia Expropriation of Land Holdings for Public Purpose and Payment of Compensation Proclamation No. 455/2005, Federal Negarit Gazeta, Addis Ababa, Ethiopia.

FDRE (2011):Lease holding of urban lands Proclamation No. 721/2011, Federal Negarit Gazeta, Addis Ababa, Ethiopia.

FDRE (1995):Constitution of the Federal Democratic Republic of Ethiopia (FDRE) Proclamation No. 1/1995, Negarit Gazeta Addis Ababa, Ethiopia.

FayeraAbdisa(2005):Urban Expansion and Livelihood of the Peri-urban Agricultural Community: the case of Addis Ababa, MA Thesis, Addis Ababa University.

Hardoy, Jorge E., et al. (2001):Environmental Problems in an Urbanizing World, Finding Solutions in Africa, Asia, and Latin America,London: Earthscan.

Jones, P.S, Young J. and Watt, A.D., (2005): Biodiversity conflict management, a report of the BIOFORM project, (available at: www.nbu.ac.uk/bioforum).

Kothari, C. (2004): Research Methodology: Methods and Techniques, $2^{\text {nd }}$ revised ed. New Age International Publications, India.

Likert, R., (1932): A technique for the measurement of attitudes. Archives of Psychology22 (140), 1-55.

Lombard M. (2012): Land tenure and urban conflict,a review of the literature, available at www.sed.manchester.ac.uk/research/gurc.16/06/2013.

Lombard M. (2016):Land conflict in peri-urban areas: Exploring the effects of land reform on informal settlement in Mexico. Urban Studies 53(13): 2700-2720.

LUCY W. MBURU (2014):An Assessment of Land Use Conflict in Peri-urban Areas of Nairobi: A Case of Drumvale Estate, RUAI, Master Thesis,University of Nairobi, Kenya.

Magsi, H. and Torre, A.(2012): Approaches to understand land use conflicts in the developing countries, The Macrotheme Conference, Paris, France.

Magsi, H., (2013): Development Projects and Land use conflicts in Pakistani rural setting, An Analysis. International Journal of Rural studies, 19(1): 3-7.

Ministry of Urban Development, Housing and Construction (MUDHC) and Ethiopian Civil Service University (ECSU)(2015): State of Ethiopian Cities Report, Addis Ababa, Ethiopia.

MinwuyeletMelesse, (2004): City Expansion, Squatter Settlements and Policy Implications in Addis Ababa: The Case ofKolfeKeranio Sub-city, Master"es Thesis, Addis Ababa University.

MWUD (2007):Plan for Accelerated and Sustained Development to End Poverty (2005/06-2009/10): Plan for Urban Development and Urban Good Governance, Ministry of Works and Urban Development, Addis Ababa, Ethiopia.

Nigussie, H., Genet, F., Atsushi, T., Mitsuru, T. and Derege, T. (2012):The Dynamics of Urban Expansion and Its 
Impacts on Land Use/Land Cover Change and Small-Scale Farmers Living Near the Urban Fringe: A Case Study of Bahir Dar, Ethiopia. Journal of Landscape and Urban Planning, 106 (2012) 149- 157.

NUPI (1997):Appraising the Urban Planning Process of NUPI for Effective Urban Development and Management, Workshop Proceedings, Addis Ababa, Ethiopia.

Robert, W. F. (2010): Boundary disputes. The U.S. Surveyor's Role. Paper presented at FIG congress, Sydney, Australia, April 2010, available at https://www.jeffcosheriff.com.

Sifuna N. (2009): Public Regulation of the Use of Private Land: Opportunities and Challenges in Kenya,5/1 Law, Environment and Development Journal (2009), available at http://www.lead-journal.org/content/09038.pdf.

SNNPRS(2006): Proclamation No.103/2006: Revised Proclamation for Cities Establishment, Hawassa, Ethiopia.

SNNPRs (2016): South Ethiopia Nations Nationalities and People Region Finance and Economic Development Bureau Annual Statistical abstract, Hawassa, Ethiopia.

Swanström and Weissmann (2005): Conflict, Conflict Prevention and Conflict Management and beyond: a conceptual exploration, Concept paper, Central Asia Caucasus Institute and Silk Road Study Programme, Uppsala University,Sweden available at www.silkroadstudies.org

Tegegn G/Egziabher (2002): Urban Policy and Strategy in Ethiopia, Report on the $2^{\text {nd }}$ National Conference on "Urban Development Planning and Implementation: Towards paving the way for partnership, May 14- 16 Adama.

TeketelFekaduZerihun(2015): Urban Expansion and Its Effects on Peripheral Farming Communities: The Case of Hosanna Town, Hadiya Zone, SNNPR, Ethiopia, M.A.Thesis, Haramaya University, Haramaya.

UN-HABITAT) (2005):United Nations Human Settlements Programme, Office of the High Commissioner for Human Rights (OHCHR): 'Indigenous Peoples Right to Adequate Housing', a Global Overview, Nairobi, Kenya.

UN-HABITAT (2014):The State of African Cities 2014, United Nations Human Settlements Programme, Nairobi, Kenya.

Wehrmann B. (2008): Land conflicts, a practical guide to dealing with land disputes, available at www.commdev.org/userfiles/08_GTZ_land_conflicts, 18062013

Wolayta Sodo Town Finance and Economic Development Office (2015):Socio-economic profile of Sodo town, unpublished document. Wolayta Sodo, Ethiopia.

Wolayta Sodo City Administration (2016):Annual Statistical Bulletin, Finance and Economic Development Bureau, Sodo, Ethiopia.

Wolayta SodoCity Municipality (2016):Municipality Annual Report, Sodo Town Municipality, Wolayta Sodo, Ethiopia.

World Bank(2005):The Dynamics of Global Urban Expansion, Transport and Urban Development Department, Washington D.C., World Bank.

Yusuf, B. Tefera, S. and Zerihun A.(2009): Land lease policy in Addis Ababa,The Addis Ababa Chamber of Commerce, Addis Ababa, Ethiopia, 2009 